\title{
Professional Associations and Library Education
}

The American Library Association (ALA), the oldest and largest professional library association in the world, has played a central role in the development of all aspects of the profession. This paper emphasizes the development of education and training for the specializations of rare books and manuscripts but will comment upon the influence of ALA on the general education for the field. The ALA model has influenced the development of a standardized curriculum, has recognized specializations that emerge in the field, and has required an educated, research-oriented faculty to provide instruction while also recognizing that expert professionals in the field have a role in formal instruction. The model requires that the formal educational program demonstrate consultation with the field as practiced. A key element in education for the profession has been the placement of formal instruction for the profession within the university.

As the public library movement developed in the United States in the latter part of the 1800s, the apprenticeship system of education was accepted practice, continuing long after the founding of Melvil Dewey's school at Columbia. The leaders in America's libraries were aware of the developments in Europe where influential librarians in Freiberg and Vienna were proposing formal, systematic educational programs for library science. And leaders in American libraries were contemplating formal programs. ${ }^{1}$ The Carnegie Corporation, supporting several important studies culminating in the C.C. Williamson report in 1923, played a major role in the developments in the United States. ${ }^{2}$ In 1919, C.C. Williamson, at the request of ALA, surveyed the library education scene in the United States and recommended to ALA that it establish a program to coordinate educational efforts for the field. ALA subsequently agreed to develop standards for library education and to measure the educational programs of the various library

1. Public Libraries in the United States: Their History, Condition, and Management (Washington, D.C.: U.S. Bureau of Education, 1876).

2. Beverly P. Lynch, "Library Education: Its Past, Its Present, Its Future," Library Trends 56, no. 4 (2008): 931-53. 
schools against those standards. This accreditation model, regularly reviewed and revised, continues as the accepted model for education for librarianship today. From the beginning, the accreditation model was designed to evaluate the beginning degree required for the field. Certification programs, $\mathrm{PhD}$ programs, and continuing education programs have not been considered in the accreditation model, which comprises the master's degree program in library and information science.

It is obvious that the accreditation of the first professional degree is an important consideration. But it is also obvious that much more education is required to meet the need of the growing and emerging specializations in the field. Specialists want certain courses - courses in their specializations - to be offered in formal programs. The programs, unwilling to add courses ad infinitum and wanting to keep the length of the degree programs within an agreeable time frame that students would find appropriate, regularly assess the needs of hiring agencies, the needs of jobs available, the interests of students. So the curriculum changes, specializations expand and contract, and the educational programs and the profession's needs for an educated workforce seek agreement.

In terms of education for the specialization of rare books and manuscripts, in the 1980s Columbia University's School of Library Service offered a series of courses in the specialization that could be taken within the context of the master's degree program. UCLA did the same. And other accredited library schools included a course or two relating to special collections in their master's curriculum. Rarely were permanent faculty hired for the rare books specializations-Columbia was one that did; the University of California, Berkeley, and UCLA were others. In general, though, for specialized courses in rare books and manuscripts, expert practitioners from the field taught them as adjunct faculty.

\section{The Development of the Rare Book and Manuscript Section in the Association of College \& Research Libraries}

The Rare Book and Manuscript Section (RBMS) of Association of College \& Research Libraries (ACRL) has played a central role in education for rare book and manuscript librarians. By enabling and supporting the many activities of its Rare Book section, ACRL has been instrumental in the development of continuing education for the specialization. In observing the achievements of the section and the division, one can see that with great leadership from the profession and agreement on the firm direction about where the field wanted to go, ACRL could and would provide the support that would get it there. Many RBMS programs are examples of that. 
There is much complexity in the climate and culture of ALA and ACRL at the time of the section's development. I have not delved into the archives in any elaborate way, relying instead on the summary reports of the Executive Secretary of ACRLand summary is the right word. There is little intellectual comment in these summaries or reporting of the ferment going on in the world of academic libraries at the time, in the early 1950s, but cryptic summaries of divisional activities are published in College \& Research Libraries.

Two important issues of Library Trends, published by the University of Illinois Library School and emphasizing topics pertaining to rare books and special collections, were issued in the 1950s. The first, "Rare Book Libraries and Collections," was edited by Howard H. Peckham, director of the Clements Library at Michigan. ${ }^{3}$ The authors of various papers in the issue are the Who's Who of rare book librarianship of the time, and the topics remain important and timely for us today. The second, "Current Trends in Antiquarian Books," edited by Hellmut LehmannHaupt, has wonderful papers on developing special collections, the training of rare book librarians, appraisals, and so on, that still have value. ${ }^{4}$

At the time of the founding of RBMS, the executive of ACRL was Arthur Hamlin. Hamlin, appointed in 1949, was only the second permanent executive secretary of ACRL. In 1955, after six years in the post, he left for the directorship of the Temple University Library. His history of the university library in the United States, published by the University of Pennsylvania Press in 1981, remains the best general history we have of the university library in the United States. ${ }^{5}$

The people the ACRL executive works with routinely are the leaders in the field of academic librarianship and higher education, but the role and job of the association executive is not the role and job of the academic library director. I can remember my frustration with an ACRL president who simply would not confront what I thought was a crucial administrative issue then before ACRL, an issue that I believed needed attention from the president. I somewhat heatedly asked why he was ducking it.

"I have to deal with these kinds of issues every day in my job," he said.

"When I come to ACRL, I want relief from that stress."

3. Howard H. Peckham, ed., "Rare Book Libraries and Collections," Library Trends 5 (Apr. 1957).

4. Helmut Lehmann-Haupt, ed., "Current Trends in Antiquarian Books," Library Trends 9 (Apr. 1961).

5. Arthur T. Hamlin, The University Library in the United States: Its Origins and Development (Philadelphia: University of Pennsylvania Press, 1981). 
While ACRL had been established before WWII and was the largest of the ALA divisions in terms of membership, had a very sophisticated publishing program (two journals, a monograph series, and, compared with other ALA divisions, a solid budget), it had no staff of its own until Orwin Rush was appointed in 1947. The ALA Council had approved a recommendation for the appointment of an academic library specialist at ALA as early as 1931, but only in 1946, when ACRL, with a growing membership and pressing needs for staff, made clear that it would consider withdrawing from ALA if there were no staff specifically assigned to it, did ALA respond with two staff: an executive secretary and a secretary. I might add that the threat of withdrawal continued into the 1970s when I was the executive secretary. The staff at that time was 3-1/2: the executive secretary, an administrative assistant, and a secretary and a half. There were three journals, a monographic series, eleven sections each with its own officers, committees, newsletters, a thriving relationship with many external organizations, and other signs of vitality. When the ACRL request for one additional full-time staff member was denied by the ALA, ACRL put in motion the major restructuring of the ALA dues structure and of the association's financial base. The result was that the divisions kept their own dues revenues and operated within the confines of those revenues. An operating agreement was negotiated between the divisions and ALA that remains very favorable to the divisions. ${ }^{6}$ The leadership of ACRL during this period was forceful, demanding, visionary, and effective. While a president may have wanted to duck an issue, rarely did he or she do so.

The committees and sections also were chaired by very able librarians with strong personalities and ideas and great influence. Let me quote from the chair of ACRL's University Libraries Section, who in 1953-54 was Lawrence Clark Powell of UCLA. This is his entire annual report of the University Libraries Section, then and now the largest of ACRL's sections:

Under my chairmanship, the University Libraries Section did absolutely nothing more than participate in two meetings, the one in Los Angeles a year ago, and the Midwinter meeting in Chicago. The first was on branch libraries and the second dealt with the problem of whether the chief librarian should be a bookman and/or administrator. Papers of the latter meeting have appeared in College \& Research Libraries. Upon taking office, I found no committees active and took no steps to activate any. ${ }^{7}$

6. American Library Association Policy Manual, section 6.4, available online at www.ala.org/ala/ aboutala/governance/policymanual/index.cfm\#S1-6\%20Units_Committees_Etc (Accessed 25 February 2010).

7. College \& Research Libraries 16 (Jan. 1955): 84. 
Vintage Powell! But Powell continued to be active and to support the work of the association and of UCLA librarians: Robert Vosper, who was president of ACRL (1955-56) and ALA (1965-66), Andrew Horn, Neal Harlow, and others from UCLA, all of whom played major roles in RBMS.

There are some wonderful recountings of the field of rare book librarianship as it was in the early 1950s. One of these is by Thomas R. Adams writing in Peckham's Library Trends volume. ${ }^{8}$ Adams neatly summarizes the development of library education as led by Melvil Dewey and places it in the context of the demise of the scholar-librarian, the collector-librarian, and the librarian who knew his books inside out. Dewey and his colleagues emphasized administration of the library, Adams says. Dewey did not teach a love of the books but how to administer a library. The image Adams gives us of the scholar-librarian could be Dewey's vision:

...the librarian who knew his books, inside and out, as intimate friends, was characterized as a stooped old man wearing a green visor, an alpaca coat, and shuffling about among dusty and disordered shelves. ${ }^{9}$

Do we like this vision any better than little lady librarian, hair in bun, who keeps wanting everyone to be quiet?

As the field of librarianship changed with more and more public libraries being established in the early years (2,240 between the years 1850 and 1875), efficiency, use, and service became the principles that were promoted; the humanistic traditions of the book as a physical object or in the literary traditions were deemphasized. The concern was on who was to administer the public libraries, what did those people need to know, and how would they find that out. At the beginning, cities and towns would send the newly appointed librarian to another town that had a reputation for having a good library and a good librarian, and have that new librarian observe for a few weeks. As the good libraries began to find this apprenticeship demand onerous, formal training programs emerged in public libraries. While this model served its purpose for a while, the Carnegie Corporation, concerned that the Carnegie Public Libraries were not staffed with the knowledgeable people they needed, supported the Williamson study of library education with the result that we have the educational programs in 57 accredited library schools that we have today. ${ }^{10}$

8. Thomas R. Adams, "Rare Books: Their Influence on the Library World," Library Trends 5 (Apr. 1957): 426-33.

9. Adams, 428 .

10. C.C. Williamson, Training for Library Service: A Report Prepared for the Carnegie Corporation of New York (New York: Carnegie Corporation, 1923). 
As Adams says, in undertaking the massive public library development, much that was vital in the "old way" of humanistic librarianship was discarded. But it was not completely discarded, and in many places the "old way" continued. There were books and collections that could not be submitted to the management designs of Dewey and the emerging educational programs for the field. In historical societies and subscription libraries, and the great and growing university libraries-Harvard, Yale, Michigan, for example - the practices of scholarly librarianship continued and, importantly, rare and special collections continued to be acquired and to grow. What also developed, unfortunately but probably inevitably, was a growing distrust of the profession of librarianship. In selecting librarians and curators for important special collections, "professional" librarians were passed over in favor of curators who could carry on the humanistic traditions of librarianship. Historians were among the favorite hires.

After the Second World War, university library collections developed, and many rare book and special collections units that had not existed before were being formed. Where would libraries get the needed staff, and what should those people know? These questions were on the minds of many university library directors. ALA and its academic library section, ACRL, were the important players in the field. And, of great significance for us today and for the rare book and manuscript community of the last 50 years, many of the university library directors looked to ALA as a potential organizational home for an emerging rare books and manuscripts program.

In 1953 John Ottemiller, the Associate Librarian at Yale, wrote to David Clift, the Executive Secretary of ALA, proposing that ALA consider a formal role for rare book librarianship within ALA. As was the policy and practice of ALA, potential activities that appeared to be a component of a particular division's activity were referred to that division for consideration. That policy and practice continues to this day, although there now is lots of overlap and a great deal more specialization. ALA has a formal association-wide Committee on Organization whose purpose is to determine issues of organizational domain. I am convinced that were such an issue come to ALA today, it would again be referred to ACRL.

Although the Association of Research Libraries (ARL) had been founded in 1932, in the early 1950s it was still a small organization, managed out of the desk drawer of Keyes Metcalf, without the complex program or influence it has today. We should note the major difference between ARL and ACRL. ARL is an organization of institutions, now about 125 of them, the largest and most prominent research libraries in North America. The directors of these libraries represent these institutions, but the directors are not the organization's members. ACRL is an organi- 
zation of individual and organizational members, now about 12,000, of which about 11,000 are individual members. It is likely that, in the early 1950 s, it did not even occur to Ottemiller or his colleagues that ARL would be the organization to which university librarians should turn to address the matter of rare books and special collections.

The February 1954 Board Minutes of ACRL report that an ad hoc committee was appointed to consider the question of a role for rare books and manuscripts. ${ }^{11}$ The committee was composed of Gerald MacDonald, chair; Hannah French, Thomas Simkins, Lawrence Clark Powell, and Clyde Walton. In June 1954, the committee reported to the ACRL Board in favor of a Rare Books Committee. I note how quickly the committee worked: four months! That is not the experience many of us have had with association committee work.

The ACRL minutes of the meeting report the reasoning behind the favorable recommendation:

This should promote wider understanding of the value of rare books to scholarly research and to cultural growth, bring improvement in the care, use and recognition of rare books in all libraries, provide for discussion of problems common to rare book libraries, and encourage librarians of these collections to become active members of ALA. ${ }^{12}$

Note the broad aims: promote wider understanding, improve care and use of rare books, provide forums for discussion. Each of these still are central to the purpose of RBMS. But then finally, the political stroke: encourage rare book libraries to become active members of ALA.

Central to the discussion was whether the committee should be placed within the ALA structure or within ACRL. At this time in ALA's history, members joining ALA would receive membership in two divisions for free, so presumably a public librarian who was in charge of a rare books department could participate in rare book activities within ACRL without having to pay any additional dues. He or she would just have to indicate the ACRL as one of the two divisions of choice. (As we know, that is no longer the case. That is, now one must first join ALA, then join — and pay dues to-ACRL and/or any of the eleven divisions. Sections within ACRL also have a dues structure, but membership in ACRL allows two free sections; more than that requires a payment of section dues. This was the result of the restructuring.)

11. College \& Research Libraries 15 (Apr. 1954): 212.

12. College \& Research Libraries 15 (Oct. 1954): 440. 
The ACRL board supported placement of the committee within ACRL, commenting that a divisional committee would have the support and assistance of a strong division with strong staff. So in 1954 the ACRL Board voted to "Authorize a Committee on Rare Books, Manuscripts, and Special Collections.”

Within three years the Rare Books Committee was recommending section status. Marjorie Wynne chaired the Committee in 1957. The solid report from Robert Vosper, who had been president of ACRL in 1955-56 and who chaired ACRL's special committee to consider section status, gave the rationale. Among the arguments were these:

Not the least important advantage of a membership group for rare book people would be the forum this would provide for self-education or inservice training, as well as recruiting. Rare book work is a field in which formal library training programs have not been very active, and this suggests a special need for a center in which rare book staff members can readily discuss matters of common interest and look toward a ready sharing of information and ideas. ${ }^{13}$

Section status was approved by a vote of the ACRL membership in a mail ballot. The section was in place by the time of the 1958 summer ALA conference in San Francisco, with Marjorie Wynne as the chair. The quality of the leadership continued: Terry Bender, Stanford, followed Wynne as chair with James Babb, Yale, in 1959-60, and Frederick Goff of the Library of Congress following him.

The Charlottesville conference was central to the section's planning and program, and announcements of it were published in College \& Research Libraries, January 1959 and March 1959. The section's leadership was astonished and gratified at the extraordinary response. Wynne's report in College \& Research Libraries of July 1959 was exuberant:

Over two hundred people-librarians, booksellers, book-collectors, and authors-gathered from all parts of the country at the University of Virginia in Charlottesville from June 18 to June 20 for the first ACRL conference devoted to the problems of collecting, housing, cataloging, and using rare books and manuscripts. ${ }^{14}$

\section{Education for the Field}

Vosper acknowledged in his report to the ACRL board that formal training programs for rare book librarians were not active and suggested that a major role for the section would be to consider education and training for the field. One of

13. College \& Research Libraries 19 (Mar. 1958): 150-52.

14. College \& Research Libraries 20 (July 1959): 320. 
the first issues taken up by the newly formed Rare Books Section was the education and training of rare book librarians. A draft manual was prepared under the direction of Richard Archer, and copies were distributed to all of the attendees at the Charlottesville conference. The first panel session, with James Wells, Cecil Bryd, and Roland Baughman participating, discussed the draft. The title of the session, according to the program, was "Scrutinizing a Rare Book Manual." There was general agreement that such a publication would be useful to library school students and to librarians just beginning to organize collections. In the early years of general library education, the matter of textbooks also was important, and texts were prepared and published on developing collections, cataloging them and so forth.

In 1965 ALA published Rare Book Collections: Some Theoretical and Practical Suggestions for Use by Librarians and Students, edited by H. Richard Archer, as ACRL Monograph Number 27. ${ }^{15}$ World Cat lists nearly 1,000 locations of this book, which is the outcome of the draft manual prepared for discussion in 1959 at the first RBMS preconference. The text begins with a chapter by Marjorie Wynne on the nature and importance of rare books. The second chapter is by Edwin Wolf and is a tour du force on "The Development of Rare Book Collections in the United States." All ten chapters are written by the leaders of the rare books field at the time.

Appended in the volume is the first policy statement prepared by RBMS: "A Statement of Recommended Library Policy Regarding Appraisals." This topic was discussed at the 1961 preconference. Just as the draft manual was first discussed at the preconference, so the first policy statement was too. RBMS pioneered the process of drafting a major policy, discussing it with the field, and revising before adopting, which it continues to this day.

\section{Solid Foundation}

I have spent some time talking about the early years of RBMS because those years set the firm foundation for the development in the United States of the specialization of rare book and manuscript librarianship.

First: outstanding leadership, which was sustained over a number of years, by people who knew their way around ALA and ACRL and knew how to get things done within the context of ALA. For example, a "preconference" was established, not a "separate conference." Neither ALA nor ACRL could object to the need to spend several days on a special topic, rare books, in advance of the ALA meeting

15. H. Richard Archer, ed., Rare Book Collections: Some Theoretical and Practical Suggestions for Use by Librarians and Students (ACRL Monograph 27) (Chicago: American Library Association, 1965). 
in Washington, particularly since all of the preconference leadership would go on to the Washington meeting as many of them had official roles in ALA/ ACRL. Probably since most of the preconference costs would be supported by the host institution, the leadership, and the conference attendees, the organizers likely said there would be no cost to ALA. The preconference was a masterful stroke of organization. It is a central part of rare book and special collection librarianship today.

Second: agreement that education regarding rare books and manuscripts was important. Instead of complaining that library schools were not doing the right thing, the section set its own educational agenda. Beginning with the 1959 Charlottesville preconference meeting, the section agreed, and has continued, to mount an annual conference on rare books and manuscripts, bringing together nationally and internationally known specialists and those new to the field to explore the important issues confronting the field. Beginning with the effort to publish what was fundamentally a textbook that could be useful in the classroom and in the library, RBMS has contributed greatly to the literature of the field. It now publishes the papers from various conferences, issues its own newsletter, and contributes significantly to the ACRL journal, RBM: A Journal of Rare Books, Manuscripts, and Cultural Heritage. RBMS mounted a first-rate educational program from its beginning. From time to time the section has set up committees to study issues pertaining to "Special Education for Training Rare Book, Manuscript, and Special Collections Librarians," and most recently prepared and adopted "Guidelines: Competencies for Special Collections Professionals." Thus it continues to bring the world of practice and the world of education together to further the aim of improving the education and training of rare book and manuscript librarians.

Third: consideration and development of policies important to the world of practice, the first one being the one of appraisals, which was adopted in 1961. The section uses its influence in the field through discussions at the various preconferences to build essential consensus on major policy issues.

RBMS has not rested on its laurels. I cannot think of a program within the American Library Association that has been sustained as the preconference has. It does it with great leadership, combining theory and practice, emphasizing the continuing development of the field by providing scholarships to students and newly minted librarians. And it does not lose money. The annual conference has enhanced the professionalization of rare book and manuscript librarians.

For professional organizations staffed mostly by volunteers, putting on an annual conference would be enough. Not for RBMS. In terms of scholarly contributions, 
the exhibition catalog award is a wonderful acknowledgement of the intellectual achievement of exhibits. The section has sixteen active committees and task forces and five discussion groups. It has continued its charge on matters of education and training, most recently publishing the Guidelines: Competencies for Special Collections Professionals and taking it through the policy adoption process of ACRL, which approved it in July 2008. Its other important policy work continues and remains current. For example, its Task Force on Guidelines for the Digitization of Special Collections is proposing recommendations, has prepared a set of "Principles for Digital Content" and a "Digitization in Special Collections Bibliography" and will place these matters before RBMS at the 2009 annual conference.

While it may be onerous for the RBMS to work within a larger organizational framework of ACRL and ALA, there are great benefits. The section leadership, well aware of these, has managed the organizational politics brilliantly.

\section{Association Membership}

It is worth examining some membership figures for ALA, ACRL, and RBMS for various years since 1954 .

\begin{tabular}{|l|l|l|l|}
\hline \multicolumn{4}{|l|}{ Table 1. Association Membership } \\
\hline Year & ALA & ACRL & RBMS \\
\hline 2009 & 66,102 & 13,010 (17 sections) & 1,866 \\
\hline 2001 & 58,275 & 12,043 (17 sections) & 1,684 \\
\hline 1994 & 55,356 & 10,379 & 1,879 \\
\hline 1975 & 33,288 & 9,324 & $1,580(1976)$ \\
\hline 1971 & 30,314 & 11,763 (11 sections) & N/A \\
\hline 1966 & 31,885 & 10,539 & N/A \\
\hline 1954 & 20,177 & 5,128 (6 sections) & N/A \\
\hline Source: Annual statistics reported in ALA Handbook of Organization; College \& Research Libraries News \\
\hline
\end{tabular}

In 1954, ACRL members were about 25 percent of ALA members. In 1966 and 1971, ACRL had about 33 percent of ALA members. In these years, people joined ALA and then could select two divisions without any additional dues. Then, in 1974, the dues structure changed. Members had to join ALA first and pay those dues, and then join a division and pay those dues. So there was, in effect, a dues increase. It led to ACRL dropping to about 20 percent of membership share, where it has stayed.

Currently, RBMS has around 15 percent of the ACRL membership. Among ACRL's seventeen sections, RBMS has the fourth largest membership; the three higher are the "type of library sections": university libraries, college libraries, and commu- 
nity college libraries. Of all the ACRL sections, RBMS has the most ambitious and influential programs.

\section{The World of Associations and the State of Education for the Field Today}

Within the last ten years much of the world of academic librarianship has changed. University library directors, confronted with the new technological landscape, and the momentous shift to digital collections, have begun to pay attention to special collections in ways most of them had not. In 2001, ARL formed a Task Force on Special Collections, which was charged to develop an action plan on issues related to special collections for consideration by the ARL and its membership. A good summary of the early work of the task force and its recommendations is presented by Joe Hewitt and Judith Panitch in Library Trends (2003). ${ }^{16}$ This issue of Library Trends, edited by Barbara M. Jones, is another remarkable publication that sets out an agenda for practice for the next few years.

In recent years, most ARL directors had neglected issues pertaining to special collections. That is no more. Special collections have moved to the forefront, and it behooves us to pay attention to what the ARL directors are thinking, saying, and doing. It is fair to say that administrative concerns loom large, and the concern has been more on what is beginning to be thought of as "heritage" collections rather than on what strategies should be used to develop collections, although consideration of issues related to born-digital materials and materials in formats other than print are emerging. ARL has construed special collections to include "distinctive material in all media and attendant library services." ${ }^{17}$ I would suggest that this definition needs some attention. Access and use, the concerns of Dewey as he looked at the emerging public libraries in the early 1900s, are the concerns of academic library directors today as they look at their special collections, built over many years without access or use being central concerns. Providing access and use to these important collections costs a lot of money, certainly an administrative concern.

The remarkable stroke of genius in talking about "hidden collections"—emerging out of its consideration in the various ARL committees-led to grant proposals and opportunities for externally funded projects to process special collection materials. The financial support of the Andrew W. Mellon Foundation and the Council on Library and Information Resources has been central to these projects

16. Joe A. Hewitt and J.M. Panitch, "The ARL Special Collections Initiative," Library Trends 52, no. 1 (2003): 157-71.

17. Special Collections in ARL Libraries: A Discussion Report from the ARL Working Group on Special Collections (Washington, D.C.: Association of Research Libraries, 2009), available online at www.arl.org/ bm $\sim$ doc/scwg-report.pdf (Accessed 25 February 2010). 
as have other, more local, foundations. The proposals from research libraries emphasize the interest these foundations and others have had in bringing into the research library subject specialists with PhDs who could learn library techniques on the job. The people who have been appointed on these grant funds to process the collections partly reflects the bias long held in academic library circles: the $\mathrm{PhD}$ in a specialized field is preferred over the MLIS in the information studies field. This hiring practice also extends the apprenticeship model of education for the field that has continued for over 100 years. There remains room for specialists educated in both traditions. We can point to the graduates of Columbia's program led by Terry Belanger as evidence of that. There also is need for solid administrative skills at the top, which is what the ARL task force is emphasizing. As Clifford Lynch notes in commenting on the draft report of May 2009, "[This is a] helpful report that will advance thinking about how to position research libraries special collections in the broad context." 18

I would hope that opportunities will come available for new graduates of MLIS programs who have knowledge, skills, and abilities in working with special collections. We need to find a way to give new graduates the on-the-job experience required in every job being advertised. Where do the new academic librarians and special collections specialists get the three years of experience all job ads call for? Some agency is expected to hire the beginner. Which one? There clearly is a programmatic need for these professionals to get that on-the-job training.

ARL's white paper on "Education and Training for Careers in Special Collections," prepared by Alice Schreyer in 2004, proposed postgraduate internships for recent graduates. ${ }^{19}$ Internships are defined as "structured pre-professional work experience which takes place during a graduate course work or after course work but preceding the degree, usually for a short amount of time." ${ }^{20}$ Instead, we should talk about residencies, defined as "The post-degree work experience designed as an entry level program for professionals who have recently received the MLS degree from a program accredited by the American Library Association." ${ }^{21}$ It would be useful and desirable to build residency programs in special collections in academic libraries to build the core of specialists with MLIS degrees in this important specialization.

\footnotetext{
18. Ibid.

19. Alice Schreyer, Education and Training for Careers in Special Collections: A White Paper Prepared for the Association of Research Libraries Special Collections Task Force, 2004.

20. "Guidelines for Practices and Principles in the Design, Operation, and Evaluation of Post Master's Residency Programs," reprinted in Internship, Residency, and Fellowships Programs in ARL Libraries, SPEC Kit 188 (Washington, D.C.: Association of Research Libraries, 1992).

21. Ibid.
} 
The current discussion report from the ARL Working Group on Special Collections was issued in March 2009. It contains seventeen recommendations on three general topics: 1) Collecting Carefully, with Regard to Costs, and Ethical and Legal Concerns; 2) Ensuring Discovery and Access; 3) The Challenge of Born-Digital Collections. Each recommendation needs our considered attention. Attention will be on "critical issues relevant to the management and use of special collections in research, teaching, and learning." 22

\section{Comment on Library Educational Programs and the Future}

In the last twenty years or so, as the field sought librarians who had training in preservation and in archives, courses have emerged in these specializations in the formal education programs offered by Schools of Library and Information Science. As issues in rare books, manuscripts, and special collections education again have become prominent and have the attention of directors of academic and research libraries, programs and courses are being designed and offered in schools such as the University of Illinois, Long Island University, and others. And important continuing education programs, such as Rare Book School at the University of Virginia and the California Rare Book School, have thrived and made important contributions to the development of the specialization, and to the education and training of people in the field.

Rare Book School at the University of Virginia, as designed and directed by Terry Belanger, has played an essential role in the development of the field and its sustainability. The model is an excellent one. We have shamelessly imitated it in the California Rare Book School at UCLA, and others have as well. There is no degree, no certification. While some course credit is worked out individually between student and institution, that is not a central component of the program. What is central is forty hours of immersion instruction on a specific subject taught by the expert in the field. This is the same amount of instruction as a fourunit course in a ten-week quarter. Immersion, I think, is the right word. It is a fine instructional model.

I have referred to library education as it has developed within the auspices of the American Library Association, but I have not spent much time on it. There is 100 years of library literature on the topic of library education, much of it tedious, boring, and haranguing. Those of us teaching in these programs should take more time to tell the field what is going on in these programs, for the borders of the discipline are porous and are expanding into areas many of us never dreamed of.

22. Special Collections in ARL Libraries: A Discussion Report from the ARL Working Group on Special Collections. 


\section{Summary Comment}

There are several successful models for the education of rare book librarians: formal programs in graduate schools of library and information science; conferences (preconferences) and workshops on specific aspects of the work generally organized and implemented by the associations; policy development; the publication of scholarly papers and textbooks often developed by leaders in the practice of the profession and in the research and teaching for the profession; and apprenticeship programs. These all serve important purposes and should continue; all of them, in their own ways, are formal programs of study.

Professional associations have been central to the development of education for our field, particularly ALA and its long-standing program of accreditation. The associations bring together the field as practiced and the field as taught in formal and informal ways that strengthen each. The associations provide the structure, the leadership, and the resources to sustain a program over time, ensuring its success. RBMS, ACRL, and ALA have proven records of excellence in educating people for the field. These efforts should be applauded and supported, for they have been essential to the continuing professionalization of the field.

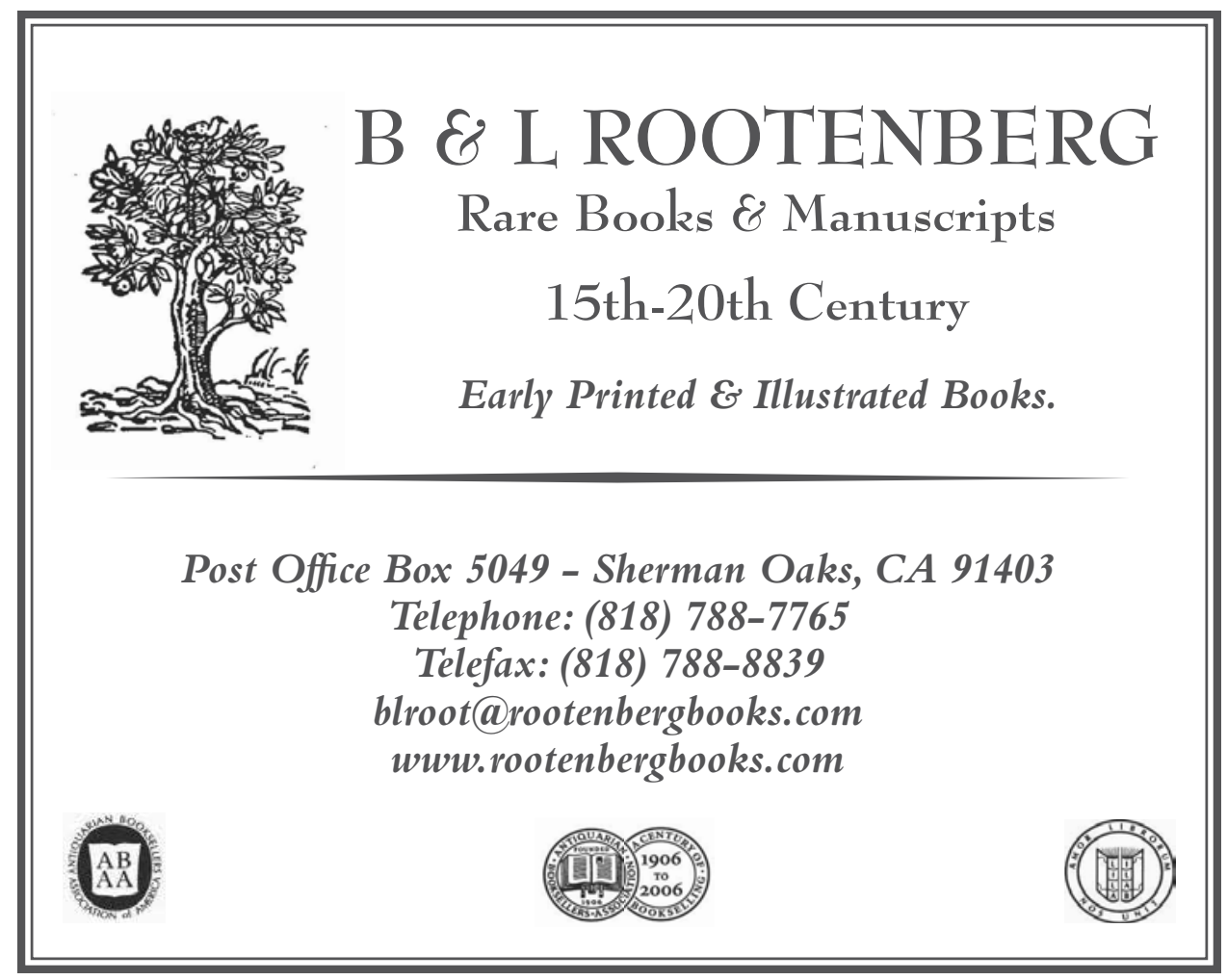

